\title{
Cognitive-behavioral and attachment interventions in the transdiagnostic treatment of bulimia nervosa and binge eating disorder
}

\author{
TAMÁS DÖMÖTÖR SZALAI \\ Semmelweis University, Institute of Behavioural Sciences, Budapest, Hungary
}

(Received: 21 April 2016, accepted: 29 July 2016)

Background: The transdiagnostic model of eating disorders provides an evidence-based cognitive-behavioral treatment approach, emphasizing the maintaining factors of low selfesteem, perfectionism, mood intolerance and interpersonal difficulties. Although attachment quality is associated with these factors, there is no treatment model focusing on both attachment-related and cognitive-behavioral maintaining factors of the symptoms. Aims: The aim was to construct and test a multilevel treatment model, which integrates attachment interventions into the transdiagnostic treatment of eating disorders. Methods: Relevant aspects of attachment functioning were joined together with the four cognitivebehavioral maintaining factors of the symptoms, and attachment interventions were incorporated into an extended transdiagnostic treatment of a bulimia nervosa and a binge eating disorder patient. Results: Attachment domains could be integrated into the transdiagnostic model of eating disorders at both the case conceptualization and treatment level. The improvement of attachment functioning was related to treatment outcomes at a one month follow-up. Conclusions: When attachment dysfunctions contribute to precipitating or maintaining mechanisms of eating disorder symptoms a multilevel treatment targeting both the relevant aspects of attachment and cognitive-behavioral functioning can be suggested. Randomized controlled studies with different intervention groups are required to confirm the result of these case studies.

Keywords: attachment, eating disorder, transdiagnostic model, treatment, case study

\section{Introduction}

\subsection{Attachment, Self-concept and Interpersonal Functioning}

Attachment is the primary affective bond between an infant and his or her primary caretaker (Bowlby, 1977). It is also a complex motivationalbehavioral system, which serves to ensure the physical and psychological

\footnotetext{
* Correspondence: Tamás Dömötör Szalai, Semmelweis University, Institute of Behavioural Sciences, 1089 Budapest, Hungary, Nagyvárad tér 4. E-mail: szalai.domotor@gmail.com
} 
safety of the child (Ainsworth, 1989). The 'internal working model' (Bowlby, 1977) of this relationship contains elementary representations of the self and the object (Bartholomew \& Shaver, 1998) and may serve as a basis for relationship dynamics (Fraley, 2002) throughout the whole life (Scharfe \& Bartholomew, 1994). This means that attachment can contribute to perceptions, expectations or affections with regard to self-object relations even in adulthood (Barholomew \& Shaver, 1998). Adult attachment consists of positive or negative concepts of the self and the object (Bartholomew \& Horowitz, 1991), and can be characterized in terms of four attachment styles derived from two primary attachment dimensions, namely anxiety or avoidance (Mikulincer, Shaver, \& Pereg, 2003). Secure attachment is characterized by positive concept of self and the other, accompanied by low anxiety and low avoidance (Griffin \& Bartholomew, 1994). Dismissive attachment is characterized by a relatively positive self-concept and negative images of others, resulting in repressed anxiety and avoidance of interpersonal contact. In preoccupied attachment the self-concept is negative while concepts of others are ambivalent; this causes strong anxiety, dependent behavior and fear of rejection (Wei, Russel, Malinckrodt, \& Vogel, 2007). Fearful attachment is characterized by negative concepts of both the self and significant others, indicating strong anxiety and high avoidance (Griffin \& Bartholomew, 1994).

\subsection{Attachment and Eating Disorders}

Attachment can influence personality development (Griffin \& Bartholomew, 1994) through its effects on relationships. Insecure attachment is associated with sensitivity to stress, disturbances in arousal, an increased probability of emotional or social conflicts, sensitive behavior, deficient ego functioning, disordered object relations, anxiety and mood disorders, and external regulation of dysphoric affect (Barholomew \& Shaver, 1998; Maunder \& Hunter, 2008; Mickelson \& Kessler, 1997; Riggs \& Jacobvitz, 2002), so it is clear that attachment has a strong influence on mental health (Oliviera \& Costa, 2009). Unoka (2007, p. 27) stated that "Attachment-based mental representations can mediate between early experiences and adult psychopathologies". The structure of the family and the communication within it, including the extent to which relationships are based on mutual trust, support and consistency, influence an individual's social competence, ability to cooperate and capacity for emotion regulation (Bowlby, 1973). Family structure and communication are also central to the concept of the psychosomatic (e.g. anorectic) family (Minuchin, Rosman, \& Baker, 2009) and the person- 
al traits which are influenced by these family characteristics are also crucial for eating disorder patients (Tasca, Ritchie, \& Balfour, 2011; Túry \& Pászthy, 2008).

As attachment can be described as a system mediating between interpersonal actions and intrapersonal experiences, similar mechanisms may underlie the relationship between attachment and eating disorders (Tasca et al., 2013). Attachment functioning can be insecure in all types of eating disorder (Ward et al., 2010); however the predominant pattern in anorexia nervosa is dismissive attachment whilst in bulimia nervosa preoccupied adult attachment is the predominant pattern (Elgin \& Pritchard, 2006; Ringer \& Crittenden, 2007; Zachrisson \& Skårderud, 2010). Bulimic patients often have ambivalent relationships characterized by anger, distrust, fear of losing the object and a strong wish for approval (Becker, Belle, \& Bellington, 1987). Broberg, Hjalmers and Nevonen (2001) demonstrated that the severity of eating disorder symptoms is related to the patient's insecurity of attachment and egocentricity, which highlights the relevance of disturbances of attachment and reflective functioning to the management of certain eating disorder patients (Tasca \& Balfour, 2014).

Orzolek-Kronner (2002) directly proposed that attachment quality should be regarded as central to the symptomatology of eating disorders, as eating disorder symptoms influence the proximity between the patient's self and primary objects, which may hint at hidden attachment dynamics. As disturbances of personality and family functioning are among the most important predisposing, precipitating and maintaining factors for eating disorders, (Túry \& Pászthy, 2008), in eating disorders attachment could be viewed as a system mediating between interpersonal and intrapersonal experiences. Attachment functioning may play a particularly important role in cases where there are comorbid psychopathologies, emotion-processing deficits, personality disorders and insecure attachment, as these patients respond less well to simple, symptom-focused therapies (Myers et al., 2006; Tasca et al., 2011). In spite of these highly important contributory mechanisms of attachment to eating disorder symptoms, mainstream treatment models emphasize the biological, cultural, or most often cognitive-behavioral traits of these disorders, without taking into account dynamic concepts or attachment issues (Tasca \& Balfour, 2014). Although, a limited number of studies evaluating attachment interventions as a treatment for eating disorders showed that improvement in attachment functioning was associated with better outcomes (Maxwell, Tasca, Ritchie, Balfour, \& Bissada, 2014; Roberts, Gotlib \& Kassel, 1996; Tasca et al., 2011; Tasca \& Balfour, 2014).

This evidence suggests that some eating disorder patients may benefit from assessment of attachment functioning and interventions designed to 
address hidden attachment disturbances (Roberts et al., 1996; Tasca et al., 2011); however the potential benefits of integrating attachment interventions into more common, evidence-based treatments has not been explored.

\subsection{The Transdiagnostic Model of Eating Disorders}

Cognitive-behavior therapy is the leading evidence-based psychotherapeutic treatment for bulimia nervosa and binge eating disorder (Fairburn, 2005; Overto, Selway, Strongman, \& Houston, 2005). The transdiagnostic model of eating disorders (Fairburn, Cooper, \& Shafran, 2003) posits that four domains of symptoms contribute to the maintenance of all types of eating disorder, including atypical eating disorders, namely (1) low core selfesteem, (2) clinical perfectionism, (3) mood intolerance and (4) interpersonal difficulties.

Eating disorder sufferers compensate for low core self-esteem through a dysfunctional self-evaluation schema characterized by: (1) the over-evaluation of eating, weight, shape control, and (2) clinical perfectionism, i.e. selfworth is judged according to the extent to which extremely high achievement expectations are fulfilled, especially with regard to body weight and shape (Fairburn et al., 2003). This can lead to dietary restraint, and physiological starving provoking binges (Anderson \& Maloney, 2001). As most patients are unable to cope effectively with adverse moods they engage in 'dysfunctional mood modulatory behaviors' which can include the eating disorder symptoms (Overton et. al., 2005). Thus, mood intolerance can play an important role in maintaining an eating disorder. Deficits in interpersonal functioning also often contribute to the escalation of symptoms (Fariburn et al., 2003).

Fairburn and colleagues (2003) proposed a transdiagnostic treatment model based on the four maintaining factors outlined above. The model was tested in a sample of non-significantly underweight (BMI > 17.5) eating disorder patients receiving outpatient care. Treatment was delivered over 20 sessions and split into four phases. The first phase of treatment based on the transdiagnostic model focuses on patient education, early behavior change and drafting a preliminary model of the case. The second phase focuses on progress and barriers to change, including personal maintaining mechanisms, in order to arrive at a revised and extended case formulation. Phase three is dedicated to reducing the presence of individual maintaining factors based on the extended case model. This is the key phase of treatment. The final phase aims to ensure continued progress and to prevent relapse. 


\subsection{The Relationship between Attachment Characteristics and Transdiagnostic Factors}

Given their differing theoretical origins it may seem at first that attachmentrelated and cognitive-behavioral models of eating disorders can be hardly integrated into the same treatment. However, unmet attachment needs can contribute to adverse moods and maladaptive interpersonal behavior (Tasca \& Balfour, 2014). Adult attachment is closely related to self-concept; the negative self-concept found in insecure attachment (Barholomew \& Horowitz, 1991) is very similar to the cognitive-behavioral key factor, negative core self-esteem. In insecure attachment, just as in clinical perfectionism, sense of self-worth is strongly associated with external reinforcements (Elliot \& Reis, 2003). Like mood intolerance, insecure attachment is also associated with poor affect regulation (Tasca et al., 2011, 2013); in preoccupied attachment distress elicits hyper-activation, whereas in avoidant attachment a deactivating strategy is used (Mikulincer et al., 2003). The insecure internal working model is often associated with over-sensitive and disturbed interpersonal behavior (Tasca et al., 2013) and damaged reflective functions (Tasca et al., 2011) and these impairments may underlie interpersonal difficulties. These relationships suggest that key domains of dysfunctional attachment may interact with the four cognitive-behavioral maintaining factors of eating disorder symptoms (Fairburn et al., 2003).

This suggests that there is an unexplored gap in current therapies that could be filled by treatments integrating interventions designed to improve attachment functioning into the transdiagnostic treatment of eating disorders. Fairburn and colleagues (2003) also highlighted that other factors can interact with cognitive-behavioral maintaining mechanisms, thus may influence outcomes in cases of eating disorder. Attachment theory has been used in case models for a long time (Markin \& Marmarosh, 2010), and mental representations of attachment are accessible from adolescence onwards (Buist, Dekovic, Meeus, \& van Aken, 2002), which means that they can be used in therapy. It has also been shown that improvements in attachment are associated with better treatment outcomes in eating disorder patients (e.g., Maxwell et al., 2014; Tasca et al., 2013). But in spite of this there has been no research which investigates treatments that target both patients' dysfunctional attachment functioning and the four transdiagnostic maintaining factors of eating disorders.

Therefore, a hypothetical multilevel model (Figure 1) was developed about the yet unexplored interactions among key domains of patients' adult 
attachment functioning and the four cognitive-behavioral maintaining factors specified in the transdiagnostic model of eating disorders (Fairburn et al., 2003).

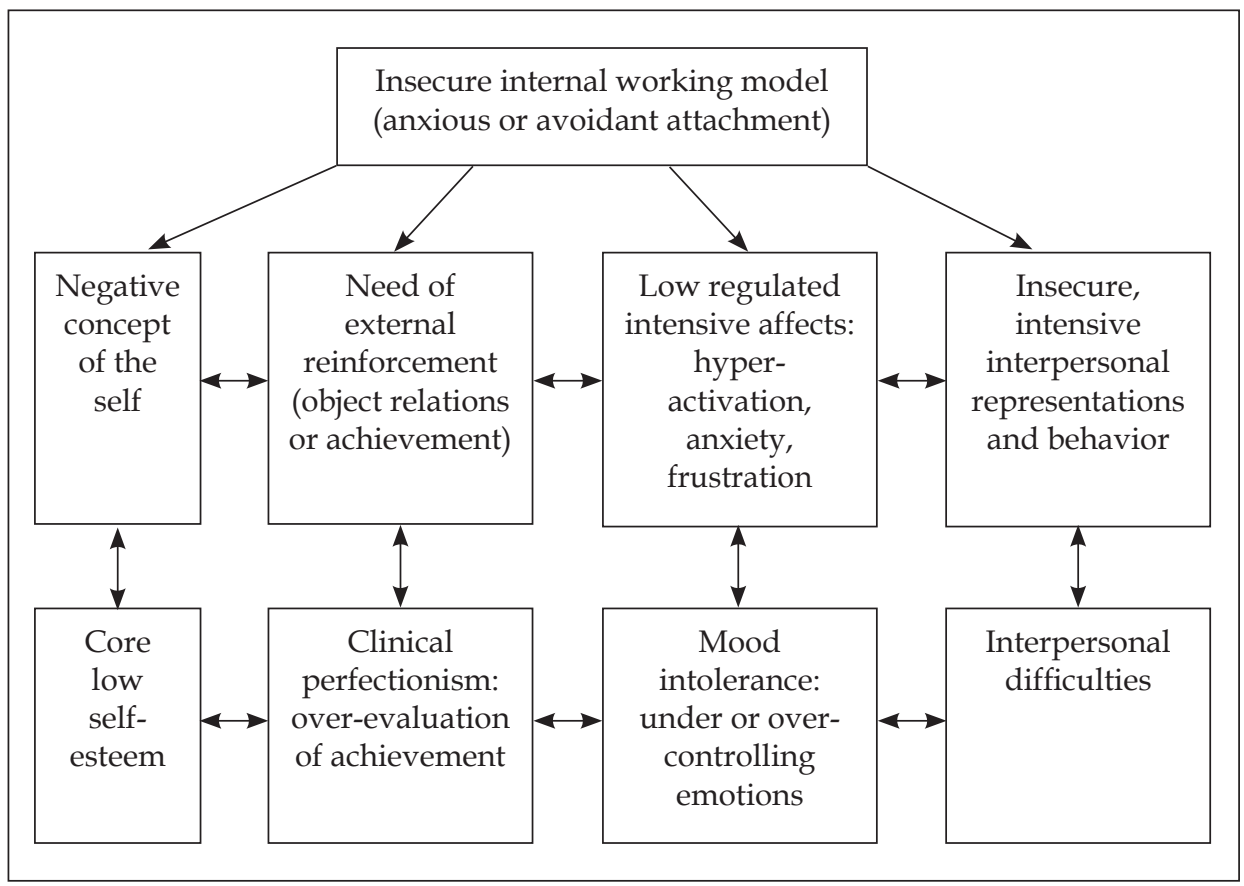

Figure 1. The hypothetical model about the interaction of the key domains of adult attachment functioning and the four cognitive behavioral maintaining factors

of the transdiagnostic model of eating disorders

\subsection{Aim and Hypotheses}

The aim was to test the hypothesized treatment model empirically in two eating disorder cases in which both attachment dysfunctions and cognitivebehavioral dysfunctions seemed to contribute to the maintenance of symptoms. It was hypothesized that attachment-related and cognitive-behavioral interventions could be integrated into personalized case models and treatments. It was also hypothesized that improvements in attachment functioning would be associated with positive outcomes. 


\section{Case Studies}

The Institute of Behavioral Sciences at Semmelweis University, Budapest has a psychosomatic clinic specializing in outpatient treatment for adults with sleep disorders, eating disorders and sexual disorders. Patients attend initial diagnostic interviews (DSM-V; APA, 2003) which are conducted by psychiatrists and then case conferences are held to distribute patients. Recently two patients presented with apparent attachment dysfunctions, which also appeared to be closely associated with the cognitive-behavioral factors maintaining their symptoms.

The referred patients had given their informed consent to be involved in the anonymized case studies before the writing and publication of this paper. Both treatments corresponded to the ethical principles of the Declaration of Helsinki and the Ethical Codex of the Hungarian Psychological Association.

\subsection{Case 1}

The first patient was a 20-year-old female engineering student with normal body mass index (BMI $=20.5)$, who complained that extremely high demands in both in her studies and sport career were affecting her courage. Her symptoms had started 7 months before the diagnostic consultation, after she had moved from her home to a dormitory. During the day she was busy and felt unable to eat, but when she got back to her room she felt lonely, stressed and hungry; this resulted in twice- or three-times weekly binges without compensatory behaviors. Her symptoms were consistent with mild binge eating disorder (APA, 2013) and included moderate fear of weight gain and critical body checking, but not serious distortions in body image. There were no serious somatic diseases and eating disorder symptoms in her anamnesis and no indications of current comorbid somatic or psychiatric complaints. She showed high need for success and perfectionism (8 points on the Dysfunctional Attitude Scale; Beck et al., 1991) and reported social frustrations and avoiding interpersonal contact. Her score on the Adult Attachment Scale (Collins \& Read, 1990) confirmed her anxious-avoidant attachment style (secure: 8, avoidant: 19, anxious/ambivalent: 12 points). The patient claimed to be highly motivated to achieve an improvement and presented good therapeutic alliance.

The treatment contract provided for 10 sessions of treatment and one follow-up session in one month; the aims were to improve her ability to cope 
with negative moods and interpersonal difficulties and to reduce her symptoms. The first phase focused on psychoeducation, normalizing her eating pattern and drafting the first case model. She was asked to read recovery guidelines (Cooper, 1995; Túry, 2005) and to keep a food diary throughout the counseling period. She completed food diaries only from the third session onwards; however she succeeded in reducing her dietary restraint and in eating five times a day from the fourth session onwards. Her attachment dysfunctions came to the fore when the factors precipitating her binges were explored in the second phase. She had a sensitive interpersonal style, and her symptoms had developed following a separation. She was afraid of losing her parents' support due to her academic and sporting failures. She reacted to stress by isolating herself, yet complained of loneliness and abandonment. Although she was aware of her negative self-image and her constant struggle for external reinforcement, she was less able to reflect on the negative spiral of her avoidant behavior, which contributed to her binges.

The extended case conceptualization integrated the key facets of her attachment functioning into the transdiagnostic model, and both cognitivebehavioral and attachment-related maintaining factors were targeted in the third phase of treatment. One of the primary aims of the attachment interventions was to improve her ability to reflect on interpersonal issues (e.g. differentiating her avoidant behavior from others' neglect). She was asked to keep a social diary as a means of reflecting on social situations and modifying unrealistic thoughts about social situations. She was also asked to notice her negative emotions and to seek mood regulation strategies. With regard to her self-concept, she was encouraged to distinguish her inherent value from her achievements and to find other sources of self-acceptance. Modifying her avoidant behavior when under stress proved difficult; however she gained insight to the vicious circle affecting her interpersonal functioning. In the closing phase of treatment she was given information about protective and risk behaviors. At the end of treatment her Adult Attachment Scale score (Collins \& Read, 1990) reflected a more secure, but still predominantly avoidant attachment with a slightly decreased tendency for avoidance (secure: 13, avoidant: 14, anxious/ambivalent: 10 points). In spite of this she reported an active social life and showed good insight into her interpersonal behavior.

The picture suggests improvement in her reflective skills and control over her attachment functioning, rather than a dramatic change in her internal working model. However, she also showed an improvement in self-esteem and reported no relapse during the follow-up period. 


\subsection{Case 2}

A 32-year-old female bookkeeper with normal body mass index (BMI = 20.3) applied for individual consultation after attending group therapy because her eating disorder remained severe. Her symptoms started after her husband had cheated on her and she participated in a fitness competition which required the complete elimination of carbohydrates and fat from meals. She had four to five binges per week followed by self-induced vomiting, which is consistent with moderately severe bulimia nervosa (APA, 2013). According to her medical reports, the patient had neither previous nor current somatic complications, she had not experienced eating disorder symptoms before the described period, and she showed no indications of current comorbid psychiatric disorders. She displayed an extremely critical attitude to her body and was lacking insight into her body image disorder; she also showed dependent personality traits and reported fluctuating mood. She suffered from alexithymia, as she showed impairments in both cognitive processing and affect regulation (Taylor, 2000), especially with respect to interpersonal situations. She complained mainly about her husband's unresponsiveness and rejection of intimacy. Her score on the Adult Attachment Scale (Collins \& Read, 1990) reflected strongly anxious and ambivalent attachment (secure: 7 , avoidant: 5 , anxious/ambivalent: 20 points). She agreed to 12 treatment sessions and 1 follow-up session in one month; the aim was to improve her emotion regulation, interpersonal functioning and her control over her symptoms. She received recovery guidelines (Cooper, 1995; Túry, 2005) and was asked to keep a food diary supplemented with notes on interpersonal concerns. She was also given tasks relating to her maladaptive body checking.

The first case conceptualization showed that her symptoms were a perfect fit to the transdiagnostic model as she had a negative self-concept and reported bodily perfectionism, dysfunctional thoughts, uncontrolled, intense moods and interpersonal difficulties. As her bulimic episodes were always precipitated by interpersonal situations with lacking insight about the precipitating factors of these situations, she was asked to draw an information graph showing the escalation of her symptoms (Figure 2).

The patient was incapable of labeling her emotions and, consistent with her alexithymia, was incapable of distinguishing between negative and positive moods so she only indicated the subjective level of her distress on the graph. Her distress increased sharply when she perceived that her husband was paying her little attention. She interpreted this as a lack of love and trustworthiness. This induced fear-arousal and catastrophization followed 
by despair and self-hatred, which precipitated her bulimic episodes. Her anxious-ambivalent attachment appeared to underlie her flustered and dependent behavior, her intense, ambivalent emotions and her wish for the constant reinforcement of intimacy and thus contributed to the maintenance of her symptoms.

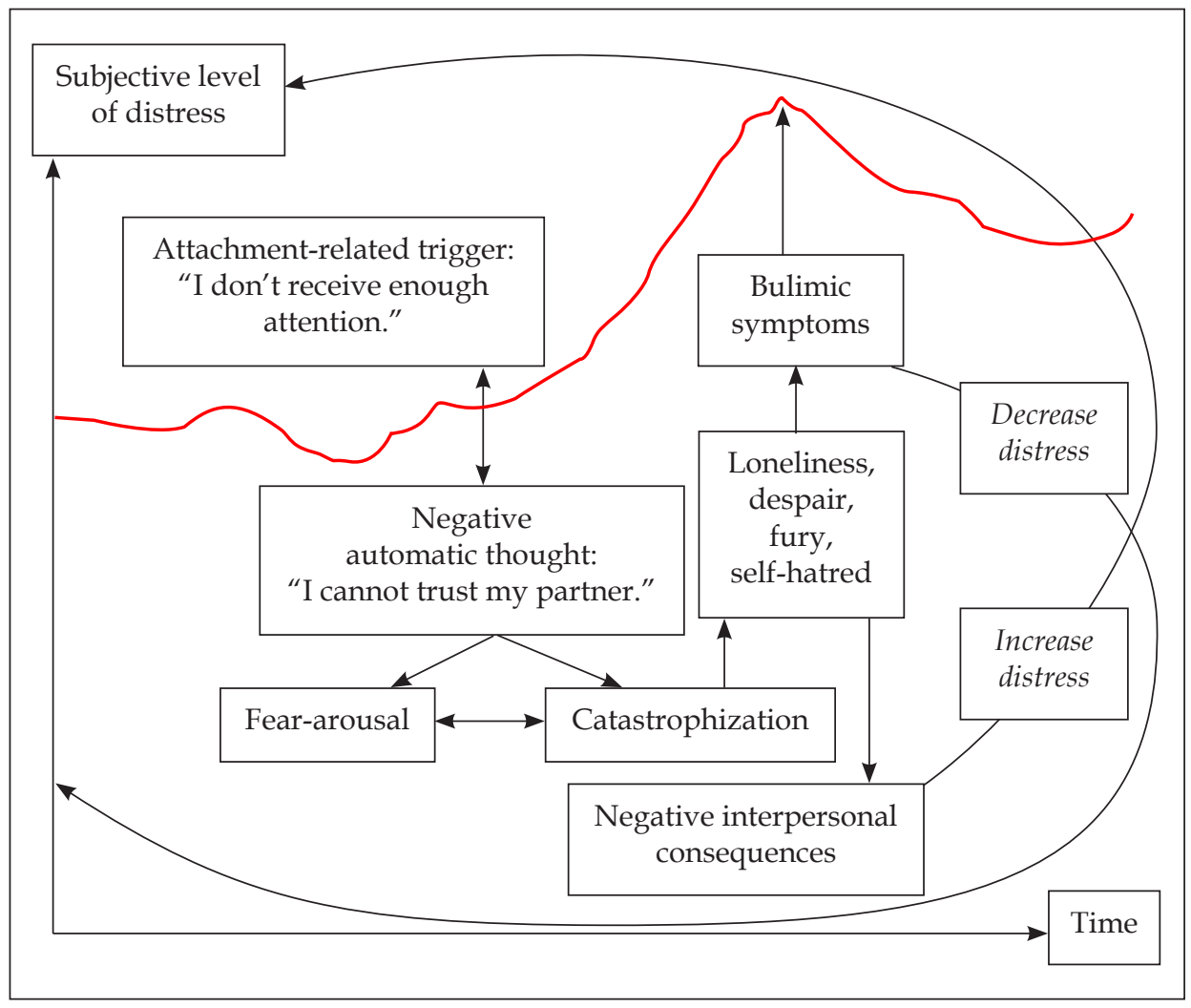

Figure 2. Information graph about the escalation of the bulimic symptoms in the second case

Because of this the second and third phases of treatment focused on enhancing her ability to reflect on her attachment functioning, including the negative interpersonal consequences of her dependence, her lack of internal resources and her poor emotion regulation and on improving her understanding of the vicious circle resulting from her misinterpretations. It was identified that her maladaptive beliefs and hyperactive response to stressful events were legacies of her parental attachment experiences and the breach of marital trust. After eight sessions she was more able to reflect on her emotions and identify the escalation of her automatic thoughts, and she 
recognized the interpersonal consequences of her behavior. Her perfectionism decreased. She found activities to regulate her distress and also gave up the maladaptive body checking and accepted most aspects of her body. She became able to maintain a normal mood for longer periods. However, her ability to reflect on others' mental states remained impaired, and she denied that her need for external reinforcement was excessive. As a result she continued to experience bulimic episodes after more severe episodes of marital conflict, approximately once a month. Because of her separation anxiety the closing phase of treatment was relatively long and during the closing phase special attention was paid to handling separation and improving emotion regulation. At the end of treatment her score on the Adult Attachment Scale (Collins \& Read, 1990) still reflected an anxious and ambivalent attachment style although there were small positive changes (secure: 9, avoidant: 10, anxious/ambivalent: 17 points).

This reflects the partial success of the treatment, which is unsurprising given that in the context of the patient's alexithymia, deep attachment dysfunctions, rather disorganized personality and marital conflicts, the duration of treatment was rather short.

\section{Discussion}

The aim of these case studies was to practically illustrate the application of the the hypothetical model, and to test its efficacy to a limited extent. Both attachment-related and cognitive-behavioral interventions were integrated into these multilevel eating disorder treatments in one bulimia nervosa and a binge eating disorder case.

\subsection{Treatment Outlines}

Both treatments consisted of an initial session, an intervention period and a follow-up session one month later. The 60 -minute sessions were broken into three stages: 1 . reviewing the food diary and changes in mood and symptoms; 2 . discussion of weekly experiences and topics based on the case model; 3. summarizing the session and setting homework. Both patients read self-help recovery guidelines (Cooper, 1995; Túry, 2005) and kept a food diary during the counseling process. As cognitive-behavioral therapy is the primary treatment for bulimia nervosa and binge eating disorder (National Institute for Health and Clinical Excellence, NICE, 2004; Hay et al., 2014), both treatment plans incorporated general cognitive-behavioral eating disorder interventions with goals such as normalization of daily meals; reducing die- 
tary restraint; reducing the tendency to over-evaluate eating, shape and weight control; avoidance of maladaptive body checking and changing maladaptive thoughts and emotions related to eating (Fairburn, 1993, 2005, 2008). Consultations were planned in accordance with the phases and focal points of the transdiagnostic model (Fairburn et al., 2003):

The first phase of treatment was focused on building rapport, patient education and constructing an initial case conceptualization. In the second phase this mode was discussed with the patient and emphasis was placed on factors influencing self-esteem and interpersonal behavior. After this there was discussion of the role of excessive control and perfectionism in the patient's disorder and emotion regulation was targeted. In both cases, when the factors precipitating and maintaining symptoms were reviewed poor attachment functioning emerged as an important contributory factor. This suggested that focusing exclusively on cognitive-behavioral interventions would have implicitly left a barrier to change unaddressed. Thus, extended case conceptualizations (Figure 3) integrated the relevant aspects of the patients' disturbed attachment functioning with the cognitive-behavioral maintaining factors described by Fairburn and colleagues (2003, p. 516).

In order to personalize the treatments the third phase not only targeted the four core transdiagnostic factors but also included a detailed assessment of patients' attachment functioning and was aimed at improving their ability to reflect on interpersonal situations in order to achieve behavior modification. Attachment interventions were used to improve patients' insight into their attachment-driven self-concepts and their images of social others, to change their emotional sensitivity and misinterpretations (e.g. distinguishing self-appraisal from others' attitudes) and to modify unrealistic, attachment-related, automatic thoughts (e.g. with social diary, or with a graph of the escalation of their symptoms) and maladaptive behavioral chain-reactions. The treatment sought to support the patients' self-concepts by encouraging them to find other sources of self-acceptance and to differentiate inherent personal value from achievements or external feedback. Patients' mood regulation was sought to improve by prompting them to attend to physical tension and emotional discomfort and seek comforting activities. Modifying the patients' avoidant and hyper-activated strategies for reducing attachment anxieties were of central importance to the treatment. In the closing phase the focus was on enabling patients' to understand their personal risk and protective factors in order to prevent severe relapses and ensure that progress was maintained. 


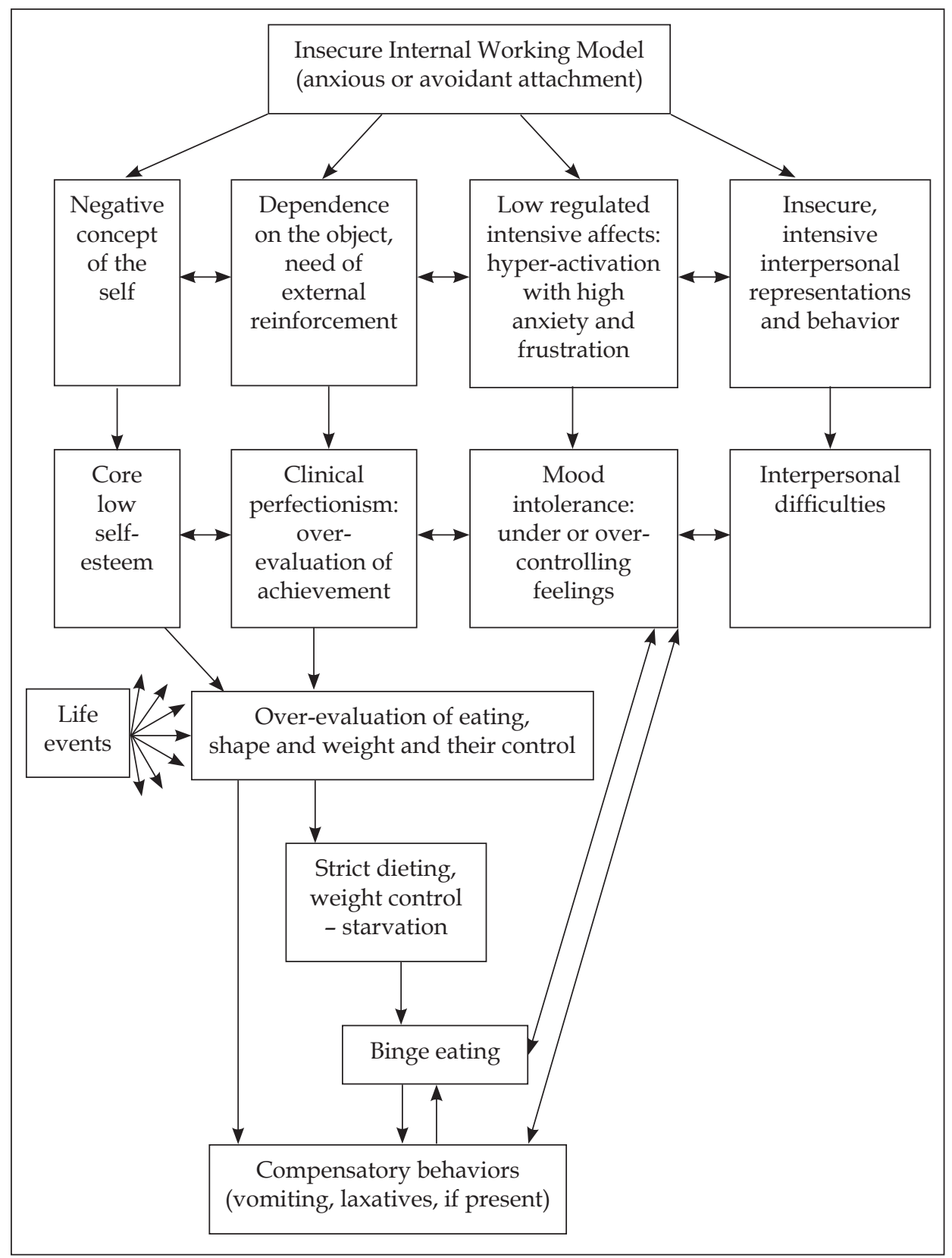

Figure 3. The interaction of attachment functioning with the four cognitive-behavioral transdiagnostic maintaining factors of the symptoms in the described cases of bulimia nervosa and binge eating disorder 


\subsection{Attachment Concerns of the Cases}

The first patient had binge eating disorder and it is well-known that the less impulsive behavior can be observed the better treatment outcomes are (Túry \& Pászthy, 2008). This patient showed better personality organization and better understanding of intrapersonal concerns than the second patient. During treatment her perfectionism decreased and her self-esteem and mood regulation improved; she was also able to make positive changes to her interpersonal life. She succeeded in counteracting her tendencies to respond to distress with social avoidance and thus, by the end of the followup period her symptoms had ceased. The second patient had moderately severe bulimia nervosa; her underlying personality organization was worse than in case of the first patient and she also had a lower reflective capability as well as worse emotion regulation. Although she gained insight into the consequences of her behavior and her mood regulation improved she showed little improvement in interpersonal reflective functions, often confusing her thoughts and others' intentions. Whilst the first patient succeeded in modifying the detachment strategy she used in stressful situations, the second patient was not able entirely to overcome her dependency and proximity seeking in interpersonal conflicts and her tendency to hyper-activation when very distressed persisted, resulting in relapses about once a month until the end of the controlled period.

Narratives of early and present relationships precisely characterize one's attachment. The accessibility of emotional memories and the coherence and integrity of the narrative reflects the representational refinement and safety of the attachment style (Main, 1991; Waters \& Waters, 2006). The first patient's narrative was coherent; she could name her emotions and recall important aspects of emotional memories, although some cognitive distortions were present. The second patient's attachment narratives were less integrated; impulsive and emotional aspects of these afterimages were barely accessible and she could not identify her major thoughts and emotions because of her alexithymia. These aspects of the case suggest avenues for further investigations.

Despite the differences, there were similarities between the two cases. Both patients had insecure attachment styles and it is known that this can contribute to a negative self-concept and to lower global self-esteem (Creasey, Kershaw, \& Boston, 1999; Lee \& Hankin, 2009). Traits common to both patients and appearing as attachment-driven precipitating factors of their symptoms were a negative self-concept, low self-esteem, strong need for external reinforcement, low mood tolerance and high interpersonal sensitivity. Both had impaired reflective functioning and low awareness of the nega- 
tive spiral of attachment-related behaviors. In both cases eating disorder symptoms had developed after apparently negative changes in their interpersonal situation.

Attachment style can be modified through actively encouraging dramatic changes in relationship patterns (Davila, Karney \& Bradbury, 1999; Waters, Weinfield \& Hamilton, 2000; Weinfield, Sroufe \& Egelund, 2000). When attachment anxiety is experienced, two distress-reducing strategies can be applied (Mikulincer et al., 2003): (1) Proximity seeking and hyper-activation, such as the flustered, dependent interpersonal functioning of the second patient. (2) Avoidance, as in the case of the first patient, who reacted to distress by isolating herself yet complained of being neglected by others. Distress reduction strategies can result in negative thoughts and use of less effective or maladaptive coping strategies (Mikulincer et al., 2003). Negative consequences of their attachment-related frustrations might have included the patients' negative automatic thoughts, their attachment-driven maladaptive interpersonal behavior and even their eating disorder symptoms, since binges can be viewed as direct attempts to reduce distress, anger, loneliness and depression or to escape from awareness (Heatherton \& Baumeister, 1991).

The binging and bulimic symptoms present in these cases might be at least partly responses to situations which provoke attachment anxiety. If this is the case it would confirm the importance of attachment experiences in the maintenance of their symptoms. In both cases there had also been disruption of primary emotional bonds so it seems likely that separation-individuation conflicts were also present. Eating disorder symptoms may distract patients' attention away from their separation-individuation problems and onto more salient eating and body concerns (Latzer, Hochdorf, Bachar, \& Canetti, 2002). This supposition was established by the association between insecure attachment, alexithymia and lower body satisfaction in eating disorder patients (Keating, Tasca, \& Hill, 2013).

Attachment changes had precipitated our patients' eating disorder symptoms and because key facets of their attachment functioning were closely associated with the cognitive-behavioral factors maintaining their symptoms, we were able to integrate attachment concepts into the personalized case models. Furthermore, attachment interventions were used successfully in both cases. Thus, the first hypothesis was confirmed. The first patient showed more improvement in attachment functioning including her interpersonal behavior, emotions and reflections, than the second patient, and these improvements were associated with a complete cessation of symptoms. The second patient was less able to counteract her primary attachment tendencies and showed little improvement in related reflections; these 
changes were associated with some improvement in her eating disorder. In these two cases improvement in attachment functioning was closely associated with treatment outcomes and thus our second hypothesis was also confirmed.

\subsection{Limitations}

The limitations of the study should be taken into account when considering the results. To date attachment functioning has not been integrated into eating disorder treatment models, which are based mainly on cognitive-behavioral mechanisms and no attachment interventions has been involved in a similar multilevel eating disorder treatment. In this study theoretical eating disorder treatment model was developed which integrates key aspects of attachment functioning and transdiagnostic factors. These cases studies did not include any patients with anorexia or an unspecified eating disorder. So far the feasibility and efficacy of our approach to treatment has been tested only on two patients; thus present study represents a limited test of the efficacy of the hypothesized model. It should also be noted that case studies cannot fully assure the methodological grounding, and randomized controlled studies will be required. At present, therefore, our treatment model remains experimental. Both treatments were relatively short and attachment styles are deeply rooted; one cannot therefore expect to achieve thorough modification in such short periods.

The development of attachment style takes place over an extended period as it is embedded in psychosocial development and the internal working model represents the structures of real interpersonal relationships. The modification of attachment pattern is recommended in an interpersonal space. The treatment and the relationship with the therapist may offer an opportunity for this; however brief therapies do not necessarily permit structural changes in a patient's relationship patterns. Modifications to the cognitive representations of relationships, improvements in ability to reflect on interpersonal encounters, better mood regulation strategies and the ability to recognize and counteract primary attachment tendencies may provide a basis for important changes in attachment functioning, but they do not guarantee that there will be substantive modification in the patient's internal working model. The more precisely an internal working model represents an individual's behavior the objects and stimuli that are important in his or her interpersonal world and the repertoire of his or her potential reactions the better that individual will be at predicting the consequences of particular actions and selecting appropriate actions, which supports the accommodation of the individual (Bowlby, 1977). Thus, attachment-related 
interventions could be designed to improve patients' ability to reflect on their attachment-related emotional, cognitive and behavioral responses. In the light of these, the improvement in the skills of interpersonal reflections, self-appraisal, mood regulation and recognizing and counteracting personal attachment functioning can be rather suspected in these cases, then the corrective formation of the internal working model. The generalizability of the findings is, therefore, limited.

\subsection{Conclusions - \\ Attachment Interventions in Eating Disorders}

To the best of the author's knowledge there has been no previous research on integrating attachment concepts and interventions into a mainly cognitive-behavioral treatment of eating disorders. It might be though that attachment theory and cognitive-behavioral therapy have theoretically different origins; thus, it may first seem that they are not well-suited to concurrent use. However, dealing with interpersonal concerns is a crucial element of most eating disorder treatments and their relevance is corroborated by studies demonstrating the efficacy of family therapy in early anorexia nervosa and interpersonal psychotherapy in bulimia nervosa and binge eating disorder (Hay et al., 2014; Wilson, Wilfley, Agras, \& Bryson, 2010). Interpersonal psychotherapy for bulimia (Fairburn, 1997) takes into account the interpersonal context in which symptoms developed and the most important interpersonal problems are taken into account in developing a personalized case model and treatment plan. The transdiagnostic model of eating disorders (Fairburn et al., 2003) also recognizes that interpersonal difficulties are among the most important maintaining factors.

Attachment style can be viewed as a mediator of interpersonal and intrapersonal concerns (Ainsworth, 1985; Bowlby, 1977), thus as an important contributory factor in recurrent interpersonal problems. Furthermore, attachment style is closely associated with one's self-concept, self-esteem, and emotional and cognitive processing of interpersonal experiences (Bartholomew \& Horowitz, 1991; Barholomew \& Shaver 1998). Secure, avoidant and ambivalent attachment styles are associated with differences in interpersonal style, reflective functioning, affect regulation and coherence of mind (Tasca et al., 2011). These facets of attachment are cognitively operationalizable and are a perfect fit with the key factors of the transdiagnostic model (Fairburn et al., 2003). This means that key facets of insecure attachment could be linked both theoretically and on the treatment level to cognitive-behavioral functioning, which suggests there is scope to integrate attachment concerns into this flexible treatment model. 
Attachment theory has long been used in personalized case conceptualizations and treatments (Markin \& Marmarosh, 2010). The therapist is an attachment figure who supports the patient by providing safety and comfort as well as encouraging the patient to explore his or her interpersonal reality autonomously. The patient's internal working model will therefore represent both the therapist's support and the patient's sense of self-worth and competence. This complementary interactional pattern of the internal working model serves an important role in personality development, and may contribute substantially to the effectiveness of treatments based on a multilevel model which incorporates attachment. This mechanism may support the integration of attachment functioning into multilevel eating disorder treatments.

Eating disorder treatments based exclusively on attachment-related interventions are rare and relatively novel, however there is evidence that they can be effective (Tasca et al., 2011, 2013, 2014). Roberts and colleagues (1996) recommended that therapists should tailor eating disorder treatments according to the patient's attachment style, paying particular attention to attachment anxiety, preoccupation with relationships, need for approval and mood regulation - factors that were targeted also in these case studies. Decreasing patients' preoccupations with their relationship concerns and their reliance on external reinforcement, and improving their affect regulation, reflective functioning and coherence of mind are all highly important to achieving a decrease in eating disorder symptoms (Roberts et al., 1996; Tasca \& Balfour, 2014). In correspondence with results of this study, Tasca and colleagues (2011) found that improvement in attachment functioning and reduction in attachment anxiety were associated with positive treatment outcomes in binge eating disorder at one-year follow-up.

On the basis of recommendations of Roberts and colleagues (1996) and Tasca and colleagues $(2011,2013,2014)$ and the interventions used in these two cases attachment interventions should have four core aims for eating disorder patients (Figure 4): (1) to increase self-acceptance, coherence of mind and the number of positive self-domains; (2) to modify their oversensitive interpersonal style and hyper-activated, dependent or avoidant distress-reduction strategies; (3) to enhance the patient's capacity for selfreflection and reflection on others; (4) to improve emotion recognition and establish personalized mood regulation strategies. 


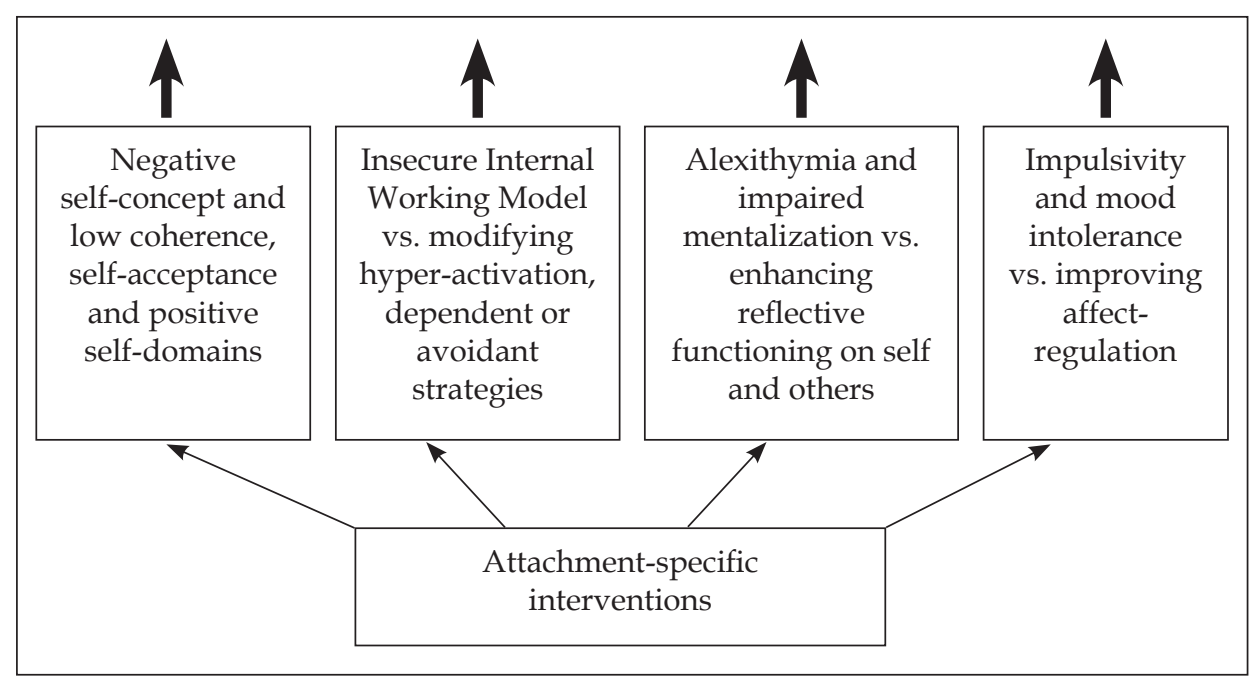

Figure 4. The four main attachment interventions applied in the described cases of bulimia nervosa and binge eating disorder

In summary, it may be important to pay special attention to eating disorder patients' attachment style in order to develop appropriate and truly personalized treatment plans. In cases where it is present, dysfunctional attachment style should be targeted with specific interventions (Roberts et al., 1996; Tasca et al., 2011; Tasca \& Balfour, 2014). Eating disorder patients whose attachment disturbances contribute to precipitating or maintaining their symptoms should be offered a multilevel treatment which targets both the key aspects of attachment functioning and the cognitive-behavioral maintaining factors of the eating disorder. Randomized controlled studies of interventions involving different subgroups of eating disorder patients are needed to compare cognitive-behavioral, attachment-based and integrated attachment and cognitive-behavioral interventions in order to establish the relative efficacy of this new approach to treatment and determine indications for its use.

\section{References}

Ainsworth, M.D.S. (1985). Attachments across the lifespan. Bulletin of the New York Academy of Medicine, 61(9), 792-812.

Ainsworth, M.D.S. (1989). Attachment beyond infancy. American Psychology, 44(4), 709-716. American Psychiatric Association. APA. (2013). Diagnostic and statistical manual of mental disorders - Fifth edition. DSM-V. Arlington: American Psychiatric Publishing. 
Bartholomew, K., \& Horowitz, L.M. (1991). Attachment styles among young adults: a test of a four-category model. Journal of Personality and Social Psychology, 61(2), 226-244.

Bartholomew, K., \& Shaver, P.R. (1998). Methods of assessing adult attachment. In J.A. Simpson, \& W.S. Rholes (Eds.), Attachment theory and close relationships (25-45). New York: The Guilford Press.

Beck, A.T., Brown, G., Steer, R.A., \& Weissman, A.N. (1991). Factor analysis of the Dysfunctional Attitude Scale in a clinical population. Psychological Assessment: A Journal of Consulting and Clinical Psychology, 3(3), 478-483.

Becker, B., Bell, M., \& Billington, R. (1987). Object relations ego deficits in bulimic college women. Journal of Clinical Psychology, 43(1), 92-95.

Bowlby, J. (1973). Attachment and loss. New York: Basic Books

Bowlby, J. (1977). The making and breaking of affectional bonds. British Journal of Psychiatry, 130(3), 201-210.

Broberg, A.G., Hjalmers, I., \& Nevonen, L. (2001). Eating disorders, attachment and interpersonal difficulties: a comparison between 18- to 24-year-old patients and normal controls. European Eating Disorders Review, 9(6), 381-396.

Buist, K.L. Dekovic, M., Meeus, W., \& van Aken, M.A.G. (2002). Developmental patterns in adolescent attachment to mother, father and sibling. Journal of Youth and Adolescence, 31(3), 167-176.

Collins, N.L., \& Read, S.J. (1990). Adult attachment, working models, and relationship quality in dating couples. Journal of Personality and Social Psychology, 58(4), 644-663.

Cooper, P.J. (1995). Bulimia nervosa \& binge-eating: a guide to recovery. New York: University Press

Creasey, G., Kershaw, K., \& Boston, A. (1999). Conflict management with friends and romantic partners: the role of attachment and negative mood regulation expectancies. Journal of Youth and Adolescence, 28(5), 523-543.

Davila, J., Karney, B.R., \& Bradbury, T.N. (1999). Attachment change processes in the early years of marriage. Journal of Personality and Social Psychology, 76(5), 783-802.

Elgin, J., \& Pritchard, M. (2006). Adult attachment and disordered eating in undergraduate men and women. Journal of College Student Psychotherapy, 21(2), 25-40.

Elliot, A.J., \& Reis, H.T. (2003). Attachment and exploration in adulthood. Journal of Personality and Social Psychology, 85(2), 317-331.

Fairburn, C.G. (2005). Cognitive-behavioral therapy for bulimia nervosa. In C.G. Fairburn, \& K.D. Brownell (Eds.), Eating disorders and obesity: A comprehensive handbook (302-307). New York: The Guilford Press

Fairburn, C.G. (2008). Cognitive behavior therapy and eating disorders. New York: Guilford Press

Fairburn, C.G., Cooper, Z., \& Shafran, R. (2003). Cognitive behaviour therapy for eating disorders: A "transdiagnostic" theory and treatment. Behaviour Research and Therapy, 41(5), 509-528.

Fairburn, C.G., Marcus, M.D., \& Wilson, G.T. (1993). Cognitive-behavioral therapy for binge eating and bulimia nervosa: a comprehensive treatment manual. In C.G. Fairburn, \& G.T. Wilson (Eds.), Binge Eating Nature, Assessment, and Treatment (361-404). New York: Guilford Press

Fairburn, C.G. (1997). Interpersonal therapy for bulimia nervosa. In D.M. Garner, \& P.E. Garfinkel (Eds.), Handbook of Treatment for Eating Disorders (67-93). New York: Guilford Press 
Griffin, D., \& Bartholomew, K. (1994). Models of the self and others: fundamental dimensions underlying measures of adult attachment. Journal of Personality and Social Psychology, 67(3), 430-445.

Hay, P., Chinn, D., Forbes, D., Madden, S., Newton, R., Sugenos, L., et al. (2014). Royal Australian and New Zealand College of Psychiatrists clinical practice guidelines for the treatment of eating disorders. Australian \& New Zealand Journal of Psychiatry, 48(11), 977-1008.

Heatherton, T.F., \& Baumeister, R.F. (1991). Binge eating as an escape from self-awareness. Psychological Bulletin, 110, 86-108.

Keating, L., Tasca, G.A., \& Hill, R. (2013). Structural relationships among attachment insecurity, alexithymia, and body esteem in women with eating disorders. Eating Behaviour, 14(3), 366-373.

Lacey, J.H., \& Evans, C.D.H. (1986). The Impulsivist: a multi-impulsive personality disorder. British Journal of Addiction, 81(5), 641-649.

Latzer, Y., Hochdorf, Z., Bachar, E., \& Canetti, L. (2002). Attachment style and family functioning as discriminating factors in eating disorders. Contemporary Family Therapy, 24(4), 581-599.

Lee, A., \& Hankin, B.L. (2009). Insecure attachment, dysfunctional attitudes, and low selfesteem predicting prospective symptoms of depression and anxiety during adolescence. Journal of Clinical Child and Adolescent Psychology, 38(2), 219-231.

Main, M. (1991). Metacognitive knowledge, metacognitive monitoring, and singular (coherent) vs. multiple (incoherent) models of attachment. In C.M. Parkes \& J. StevensonHinde (Eds.), Attachment cross the life cycle (127-159). New York: Routledge

Markin, R.D., \& Marmarosh, C. (2010). Application of adult attachment theory to group member transference and the group therapy process. Psychotherapy: Theory, Research, Practice, Training, 47(1), 111-121.

Maunder, R.G., \& Hunter, J.J. (2008). Attachment relationships as determinants of physical health. The Journal of the American Academy of Psychoanalysis and Dynamic Psychiatry, 36(1), 11-32.

Maxwell, H., Tasca, G.A., Ritchie, K., Balfour, L., \& Bissada, H. (2014). Change in attachment insecurity is related to improved outcomes 1-year post group therapy in women with binge eating disorder. Psychotherapy, 51(1), 57-65.

Mickelson, K.D., \& Kessler, R.C. (1997). Adult attachment in a nationally representative sample. Journal of Personal and Social Psychology, 73(5), 1092-1106.

Mikulincer, M., Shaver, P.R., \& Pereg, D. (2003). Attachment theory and affect regulation: The dynamics, development, and cognitive consequences of attachment-related strategies. Motivation and Emotion, 27(2), 77-102.

Minuchin, S., Rosman, B.L., \& Baker, L. (2009). Psychosomatic families: Anorexia nervosa in context. Boston: Harvard University Press

Myers, T.C., Wonderlich, S.A., Crosby, R., Mitchell, J.E., Steffen, K.J., Smyth, J., et al. (2006). Is multi-impulsive bulimia a distinct type of bulimia nervosa: Psychopathology and EMA findings. International Journal of Eating Disorders, 39(8), 655-661.

National Institute for Health and Clinical Excellence. NICE. (2004). Eating disorders. Core interventions in the treatment and management of anorexia nervosa, bulimia nervosa and related eating disorders: a national clinical practice guideline. London: NICE

Oliviera, P., \& Costa, M.E. (2009). Interrelationships of adult attachment orientations, health status and worrying among fibromyalgia patients. Journal of Health Psychology, 14(8), 1184-1195. 
Orzolek-Kronner, C. (2002). The effect of attachment theory in the development of eating disorders: can symptoms be proximity-seeking? Child and Adolescence Social Work Journal, 19(6), 421-435.

Overton, A., Selway, S., Strongman, K., \& Houston, M. (2005). Eating disorders - The regulation of positive as well as negative emotion experience. Journal of Clinical Psychology in Medical Settings, 12(1), 39-56.

Riggs, S.A., \& Jacobvitz, D. (2002). Expectant parents' representations of early attachment relationships: associations with mental health and family history. Journal of Consulting and Clinical Psychology, 70(1), 195-204.

Ringer, F., \& Crittenden, P.M. (2007). Eating disorders and attachment: The effects of hidden family processes on eating disorders. European Eating Disorders Review, 15(2), 119-130.

Roberts, J.E., Gotlib, I.H., \& Kassel, J.D. (1996). Adult Attachment Security and Symptoms of Depression: The mediating roles of dysfunctional attitudes and low self-esteem. Journal of Personality and Social Psychology, 70(2), 310-320.

Scharfe, E., \& Bartholomew, K.I.M. (1994). Reliability and stability of adult attachment patterns. Personal Relationships, 1(1), 23-43.

Tasca, G.A., \& Balfour, L. (2014). Eating Disorders and Attachment: A Contemporary Psychodynamic Perspective. Psychodynamic Psychiatry, 42(2), 257-276.

Tasca, G.A., Ritchie, K., \& Balfour, L. (2011). Implications of attachment theory and research for the assessment and treatment of eating disorders. Psychotherapy, 48(3), 249-259.

Tasca, G.A., Ritchie, K., Zachariades, F., Prolux, G., Trinneer, A., Balfour, L., et al. (2013). Attachment insecurity mediates the relationship between childhood trauma and eating disorder psychopathology in a clinical sample: A structural equation model. Child Abuse \& Neglect, 37(11), 926-933.

Taylor, G.J. (2000). Recent developments in alexithymia theory and research. The Canadian Journal of Psychiatry/La Revue canadienne de psychiatrie, 45(2), 134-142.

Túry, F. (2005). Anorexia és bulimia. Önsegítő és családsegítő kalauz. [Anorexia and bulimia. Self-help book for patients and relatives.] Budapest: Print-X

Túry, F., \& Pászthy, B. (2008). Evészavarok és testképzavarok. [Eating disorders and body image disorders.] Budapest: Pro Die Kiadó

Unoka, Zs. (2007). Személyiségvonások, tünetdimenziók, rossz szülői bánásmód vizsgálata és látens sérülékenységdimenziók azonosítása egyes pszichés zavarokban. Doktori értekezés. [Identifying personality traits, symptom dimensions, bad early parental treatment and latent vulnerability dimensions in certain psychic disorders. PhD Dissertation] Budapest: Semmelweis Egyetem. Retrieved from: http://phd.semmelweis.hu/mwp/phd_live/vedes/export/unokazsolt. d.pdf 01.03.2016.

Ward A., Ramsay R., Treasure J. (2010). Attachment research in eating disorders. British Journal of Medical Psychology, 73(1), 35-51.

Waters, E., Weinfield, N.S., \& Hamilton, C.E. (2000). The stability of attachment styles from infancy to adolescence and early adulthood: General discussion. Child Development, 71(3), 703-706.

Waters, H.S., \& Waters, E. (2006). The attachment working models concept: Among other things, we build script-like representations of secure base experiences. Attachment $\mathcal{E}$ Human Development, 8(3), 185-197.

Wei, M., Russell, D.W., Mallinckrodt, B., \& Vogel, D.L. (2007). The Experiences in Close Relationship Scale (ECR)-short form: Reliability, validity, and factor structure. Journal of Personality Assessment, 88(2), 187-204. 
Weinfield, N.S., Sroufe, L.A., \& Egelund, B. (2000). Attachment from infancy to early adulthood in a high-risk sample: Continuity, discontinuity, and their correlates. Child Development, 71(3), 695-702.

Wilson, G.T., Wilfley, D.E., Agras, W.S., \& Bryson, S.W. (2010). Psychological treatments of binge eating disorder. Archives of General Psychiatry, 67(1), 94-101.

Young, J.E. (1994). Cognitive therapy for personality disorders: A schema-focused approach. Sarasota: Professional Resource Press/Professional Resource Exchange

Zachrisson, H.D., \& Skårderud, F. (2010). Feelings of insecurity: Review of attachment and eating disorders. European Eating Disorders Review, 18(2), 97-106.

\title{
Conflict of Interests Statement
}

The author declares that he has no conflict of interest. The author was supported by the UNNK-16-3-IV New National Excellence Program of the Ministry of Human Capacities.

\section{Kognitív-viselkedéses és kötődési intervenciók a bulimia nervosa és a falászavar transzdiagnosztikus kezelésében}

\author{
SZALAI TAMÁS DÖMÖTÖR
}

Elméleti háttér: Az evészavarok transzdiagnosztikus modellje egy bizonyított kognitív viselkedésterápiás megközelítést kínál, amely az alacsony önértékelés, perfekcionizmus, hangulatintolerancia és interperszonális zavarok szerepét hangsúlyozza. Bár a kötődés minősége összefüggést mutat e tényezőkkel, egyetlen evészavar-kezelési modell sem fókuszál a tünetek kötődéssel kapcsolatos és kognitív-viselkedéses fenntartó tényezőire egyaránt. Cél: A cél egy hipotetikus többszintú kezelési modell építése és tesztelése volt, amely kötődési intervenciókat integrál az evészavarok transzdiagnosztikus kezelésébe. Módszerek: A kötődés releváns aspektusait és a tünetek négy kognitív-viselkedéses fenntartó tényezőjét összekapcsolva kötődési intervenciókat alkalmaztunk egy bulimia nervosa és egy falászavaros beteg kibővített transzdiagnosztikus kezelésében. Eredmények: A kötődés aspektusai illeszkedtek az evészavarok transzdiagnosztikus modelljébe, az esetkonceptualizációk és a kezelés szintjén egyaránt. A kötődési funkciók javulása kapcsolatot mutatott a kezelés eredményeivel egy hónap után is. Következtetések: Ha a kötődési diszfunkciók hozzájárulnak az evészavar-tünetek kiváltó- vagy fenntartó mechanizmusaihoz, többszintú kezelés lehet ajánlott, amely a kötődés releváns aspektusait és a kognitív-viselkedéses funkciókat egyaránt célozza. Különböző intervenciós csoportokon végzett, randomizált, kontrollált vizsgálatok szükségesek a jelen esettanulmányok eredményeinek megerősítéséhez.

Kulcsszavak: kötődés, evészavar, transzdiagnosztikus modell, kezelés, esettanulmány 